\title{
Impact of body mass index on the psychopathological profile of obese women
}

\section{Impacto do índice de massa corporal no perfil psicopatológico de mulheres obesas}

\author{
Marcelo Papelbaum, ${ }^{1}$ Rodrigo Oliveira Moreira, ${ }^{1,2,3}$ Caroline Wust do Nascimento Gaya, ${ }^{1,2}$ \\ Carolina Preissler, ${ }^{1,2}$ Walmir Ferreira Coutinho ${ }^{1,2}$
}

1 Grupo de Obesidade e Transtornos Alimentares (GOTA), Instituto Estadual de Diabetes e Endocrinologia (IEDE) e Instituto de Psiquiatria da Universidade Federal do Rio de Janeiro (IPUB/UFRJ), Rio de Janeiro (RJ), Brazil

2 Pontifícia Universidade Católica do Rio de Janeiro (PUC-RJ), Rio de Janeiro (RJ), Brazil

3 Centro de Ensino Superior de Valença, Fundação Educacional Dom Andre Arcoverde, Valença (RJ), Brazil

\begin{abstract}
Objective: Obesity is a complex condition associated with a host of medical disorders. One common assumption is that obesity is also related to psychological and emotional complications. However, some studies have shown that obesity itself does not appear to be systematically associated with psychopathological outcomes. The objective of the present study was to evaluate the impact that the various degrees of obesity have on the psychopathological profile of obese patients. Method: The study sample consisted of 217 women classified as obese (body mass index $\geq 30 \mathrm{~kg} / \mathrm{m}^{2}$ ) who sought medical treatment for weight loss and were consecutively invited to participate in the study. Anthropometric data were registered for all participants. Psychiatric evaluations were performed using the Beck Depression Inventory and Symptom Checklist-90. Multiple regression analysis was used in order to determine whether any of the studied variables (age, level of education, Beck Depression Inventory score and body mass index) were independently correlated with the score on the different subscales of the Symptom Checklist-90. Results: Only body mass index was found to correlate significantly with the score on the somatization subscale of the Symptom Checklist-90 $(r=0.148, p=0.035)$. This correlation remained significant after multiple regression analysis $(\mathrm{p}=0.03)$. No correlation was found between body mass index and the score on any of the other subscales. Conclusion: The degree of obesity did not correlate with any of the psychological profiles commonly described in the medical literature, including depression and anxiety. The correlation between obesity and somatization, although weak, might simply be related to an overlapping of symptoms.
\end{abstract}

Descriptors: Obesity; Linear models; Somatoform disorders; Body Mass Index

\section{Resumo}

Objetivo: A obesidade é uma condição complexa associada a uma ampla variedade de desordens médicas, incluindo alguns distúrbios emocionais e psicológicos. Entretanto, alguns estudos têm demonstrado que a obesidade, per se, não parece estar sistematicamente associada a alteraçôes psicopatológicas. O objetivo deste estudo foi avaliar o impacto da severidade da obesidade no perfil psicopatológico de pacientes com obesidade, utilizando o Symptom Checklist-90. Método: Foram selecionados 217 pacientes do sexo feminino, com obesidade (indice de massa corporal $\geq 30 \mathrm{~kg} / \mathrm{m}^{2}$ ), que procuraram tratamento para perda de peso. Os participantes tiveram seus dados antropométricos registrados. A avaliação psiquiátrica foi realizada utilizando o Inventário de Depressão de Beck e o Symptom Checklist-90. A Regressão Linear Múltipla foi utilizada para avaliar quais variáveis (idade, nivel educacional, Inventário de Depressão de Beck e indice de massa corporal) apresentariam uma correlação independente com as subscalas do Symptom Checklist-90. Resultados: Uma correlação significativa foi encontrada apenas entre o indice de massa corporal e o domínio Somatização $(r=0,148$, $p=0,035)$. Esta correlação permaneceu após análise de regressão múltipla ( $p=0,03)$. Nenhuma correlação foi encontrada entre indice de massa corporal e os outros domínios. Conclusão: A gravidade da obesidade não se correlacionou com diversos dos perfis psicopatológicos comumente encontrados na literatura, como depressão e ansiedade. A correlação entre obesidade e somatização, embora fraca, pode estar relacionada simplesmente a uma sobreposição de sintomas.

Descritores: Obesidade; Modelos lineares; Transtorno de somatização, Índice de Massa Corporal

\section{Introduction}

Obesity is currently one of the most serious public health problems. Its prevalence has been on the rise in recent decades, even in developing countries. To date, obesity has been considered a global epidemic not limited to any specific region, country or racial/ethnic group. In Brazil, the available data indicate that $8.9 \%$ of men and $13.1 \%$ of women are obese. ${ }^{1}$ It is estimated that there 
are 300 million obese individuals worldwide, and this number is expected to double by 2025 . $^{2,3}$

The rising incidence of obesity in different populations suggests that certain environmental factors are responsible for this epidemic. It has been proposed that $24-40 \%$ of the variance in body mass index (BMI) can be attributed to genetic factors that affect basal metabolic rate responses and the response to overfeeding. ${ }^{4}$ A sedentary lifestyle is associated with changes in eating habits, which have an effect on the susceptibility genes and are thought to constitute the main determinant of the increasing incidence of obesity worldwide. It is likely that obesity results from an interaction between polygenic factors and an obesogenic environment. ${ }^{5}$

Although it seems clear that the vulnerability to obesity is largely determined biologically, the psychological correlates might also be highly relevant. Researchers have long been studying the psychological profile of obese individuals. In the 1950 s, the notion that obese individuals had a unique personality was questioned, and recent empirical studies have failed to detect any such personality type. ${ }^{6}$ In studies of community samples, obese individuals generally do not have a greater psychological distress rate than do normal-weight subjects. ${ }^{7}$ In contrast, various clinical studies have indicated that the rates of depression are higher among obese individuals seeking medical treatment for weight loss than among non-obese individuals. ${ }^{8}$ However, obese individuals have also been found to present a lower prevalence of anxiety disorders (including agoraphobia, specific phobia and post-traumatic stress disorder), bulimia nervosa, smoking and borderline personality disorder. ${ }^{9}$ This disparity between community and clinical samples might indicate that individuals presenting any comorbidity are likely to be more disturbed and therefore more likely to seek treatment for the main disorder. When clinical populations are investigated, a finding of a psychiatric disorder is relevant and must be considered in the evaluation of obese patients.

When it comes to the psychological investigation, there are many instruments currently used in research and clinical practice for the symptomatic evaluation of behavior disorders. ${ }^{10}$ The Symptom Checklist-90 (SCL-90) is a scale commonly used to measure psychopathology in outpatients. The scale is composed of 90 items and organized into nine primary symptom subscales and three global indices of distress (the Global Severity Index, the Positive Symptom Distress Index and the Positive Symptom Total). ${ }^{11}$ The SCL-90 is easily applied and is easily understood by the responders. In addition, it is widely recognized in the medical literature as an instrument capable of evaluating psychological symptoms in patients with or without physical illness. ${ }^{12}$

The objective of this study was to evaluate the impact that the degree of obesity has on the psychopathological profile of obese patients. To that end, the SCL-90 was employed.

\section{Patients and Method}

\section{Study population}

Two hundred and seventeen female patients classified as obese $\left(\mathrm{BMI} \geq 30 \mathrm{~kg} / \mathrm{m}^{2}\right)$, ranging in age from 18 to 75 years and seeking medical treatment for obesity were sequentially evaluated by the Grupo de Obesidade e Transtornos Alimentares (Obesity and Eating Disorders Group) at the Instituto Estadual de Diabetes e Endocrinologia do Rio de Janeiro, a referral center located in the city of Rio de Janeiro, Brazil. The protocol was approved by the local ethics committee (CEP-IEDE 004-08).

The exclusion criteria were as follows: inability to understanding the scales due to an insufficient level of education; type 2 diabetes; any organic disease associated with obesity (including overt hypothyroidism and Cushing's syndrome); history of bariatric surgery; any psychiatric disorder under pharmacological treatment; and any other condition that, in the opinion of the researcher, might impede the understanding or completion of the scales.

\section{Anthropometric evaluation}

The following anthropometric data were registered: body weight $(\mathrm{kg})$, height $(\mathrm{m})$, and BMI. BMI was calculated as weight in kilograms divided by height in meters squared $\left(\mathrm{kg} / \mathrm{m}^{2}\right)$.

\section{Psychopathological evaluation}

The severity of depressive symptoms was assessed using the Beck Depression Inventory (BDI). The Portuguese-language version of the BDI used in this study has been validated in nonclinical populations. $^{13}$

The SCL-90 is a multidimensional inventory designed to evaluate a wide spectrum of psychological problems and psychopathological symptoms. It is composed of 90 items, which are graded on a five-point scale, from 0 ("not at all") to 4 ("extremely"). The items are organized into nine primary symptom subscales: somatization; obsessive-compulsive; interpersonal sensitivity; depression; anxiety; hostility; phobic anxiety; paranoid ideation; and psychoticism. The scores on these subscales are used for the calculation of the Global Severity Index. The SCL-90 has been translated into Portuguese and validated for use in Brazil. ${ }^{12}$

\section{Sociodemographic factors}

Initially, all participants were examined using a sociodemographic questionnaire. The level of education was expressed as the total number of years of formal education completed by each patient. Marital status was categorized as married (living with a partner) or unmarried (living alone). Family income was expressed in units of the Brazilian national minimum wage, currently equivalent to $150 \mathrm{USD} / \mathrm{month}$.

\section{Statistical analysis}

Statistical analysis was performed with GraphPad InStat 3.00 for Windows 95 (GraphPad Software, San Diego, CA, USA). The strength of the linear relationship between two continuous variables was evaluated by Pearson's correlation coefficient or Spearman's correlation coefficient. Multiple linear regression analysis was used in order to determine the independent effect that the variables age, level of education, $\mathrm{BMI}$ and $\mathrm{BDI}$ score have on the score on the somatization subscale of the SCL-90. The level of statistical significance was set at $5 \%(\mathrm{p} \leq 0.05)$. 
Table 1 - General features of the $\mathbf{2 1 2}$ obese women studied

\begin{tabular}{lc}
\hline Variable & $\mathbf{n = 2 1 2}$ \\
\hline Age (years) & $38.4 \pm 11.9$ \\
Level of education & \\
$\quad \leq 8$ years of schooling & $62(29.2 \%)$ \\
$\quad \leq 11$ years of schooling & $94(44.3 \%)$ \\
$\quad$ Some college or college & $56(26.4 \%)$ \\
$\quad$ diploma & 110 \\
Married & $2.1 \pm 1.0$ \\
Family income (no. of $\times$ the MW) & $40.3 \pm 7.3$ \\
BMI (kg/m ${ }^{2}$ ) & $20.2 \pm 10.3$ \\
Beck Depression Inventory & \\
score &
\end{tabular}

MW: minimum wage; $B M I$ : body mass index

Data expressed as mean \pm standard deviation or as $n(\%)$

\section{Results}

Of the 217 patients evaluated, 5 were excluded due to serious errors made on the SCL-90. The characteristics of the patients are shown in Table 1.

The relationship between the degree of obesity (BMI) and the scores on the various SCL-90 subscales was assessed, and a significant correlation was found for the score on the somatization subscale $(r=0.148, p=0.035)$. None of the other subscale scores were found to correlate significantly with BMI: obsessivecompulsive $(r=-0.05, \mathrm{p}=0.40)$; interpersonal sensitivity $(\mathrm{r}=0.05$, $\mathrm{p}=0.41)$; depression $(\mathrm{r}=0.04, \mathrm{p}=0.54)$; anxiety $(\mathrm{r}=0.03$, $\mathrm{p}=0.63)$; hostility $(\mathrm{r}=0.03, \mathrm{p}=0.61)$; phobic anxiety $(\mathrm{r}=0.01, \mathrm{p}=0.80)$; paranoid ideation $(\mathrm{r}=0.03, \mathrm{p}=0.64)$; and psychoticism $(r=0.01, p=0.83)$. In addition, BMI did not correlate significantly with the General Severity Index $(r=0.04, p=0.51)$.

In order to identify possible confounding factors, we also attempted to determine whether the score on the somatization subscale correlated with any of the sociodemographic variables or with the presence of depressive symptoms. We found the somatization subscale score to correlate significantly with age $(r=0.20, p=0.034)$, level of education $(r=-0.13$, $\mathrm{p}=0.05)$ and BDI score $(\mathrm{r}=0.51, \mathrm{p}<0.001)$. On the other hand, the somatization subscale score did not correlate with family income $(\mathrm{r}=-0.07, \mathrm{p}=0.29)$ or with marital status $(\mathrm{r}=0.057$, $\mathrm{p}=0.40)$. After multiple linear regression, age $(\mathrm{p}=0.006)$, BDI $(\mathrm{p}<0.001)$ and BMI $(\mathrm{p}=0.03)$ remained independently correlated with the somatization subscale score.

\section{Discussion}

This study assessed a consecutive sample of 212 obese women seeking treatment for weight loss. The psychopathological profile of the patients was evaluated with two well-known instruments: the BDI and the SCL-90. In seeking significant correlations between the degree of obesity and changes in the psychopathological profile of these patients, we found such a correlation only between the degree of obesity and the somatization subscale of the SCL-90. In contrast with the findings of some other studies of the literature, we found no relationship between the degree of obesity and other psychiatric comorbidities, such as depression and anxiety.

In recent years, many studies have shown that the incidence psychopathological disturbances among obese individuals is equal to that observed among non-obese individuals. ${ }^{14}$ In our series, the only significant correlation identified was between the degree of obesity and the somatization subscale score. In accordance with our findings, Petroni et al. demonstrated that the score on the somatization subscale of the SCL-90 and weight cycling were the only factors capable of impairing the mental health of individuals with morbid obesity. ${ }^{15}$ These results also coincide with those of Rosik et al., who demonstrated that behavioral changes are present in nearly half of all morbidly obese patients. In their study, somatization also represented the main psychiatric disorder found in those individuals. ${ }^{16}$ Finally, Guisado et al. evaluated patients with morbid obesity submitted to bariatric surgery and also observed psychiatric disorders, highlighting affective disorders such as somatization and anxiety. ${ }^{17}$

Somatization can be defined as a tendency to experience and communicate disorders and somatic symptoms not explained by pathological findings (i.e., expressions of physical complaints for which there are no corresponding organic injuries). The emotional suffering of individuals with such complaints prompts them to seek medical attention. Somatization disorders are more common in women, in whom the symptoms tend to be more serious, and generally tend to be triggered by psychosocial stress. ${ }^{18}$ In our society, obese individuals typically experience high levels of stress, comparable to those experienced by individuals who have lost their jobs, are in a state of mourning or are going through a divorce. This is probably related to the strong social representation of the obese individual as an unqualified person who has no willpower, has low self-esteem and ignores aesthetic standards. ${ }^{19}$ Therefore, obesity can be considered a factor that might influence the development and maintenance of somatization disorder.

In contrast to our findings, several studies in the literature have demonstrated a significant correlation between obesity and psychiatric comorbidities. Sullivan et al. found that female patients with a BMI $>35 \mathrm{~kg} / \mathrm{m}^{2}$ had a higher prevalence of depressive symptoms and anxiety in comparison with other groups. ${ }^{20}$ Similar results were obtained in various other studies, ${ }^{21-23}$ come of which involved community samples. For instance, in a sample of adults residing in the United States, Simon et al. noted that obesity is associated with an increase of approximately $25 \%$ in the risk of eating disorders and anxiety. ${ }^{24}$ In a study conducted in Brazil, Moreira et al. found that obesity, per se, seems to be an independent variable associated with the severity of depressive symptoms and the prevalence of mood disorders in obese women. ${ }^{25}$ Recent studies have identified specific risk factors for psychopathology in obese subjects, including female gender, binge eating and greater degree of obesity. ${ }^{26}$ However, it should be borne in mind that these variables are also considered risk factors for psychopathological disturbances in non-obese individuals. ${ }^{26}$ 
Another hypothesis to explain these discrepant findings related to obesity and psychopathology is that there is considerable heterogeneity among the instruments employed in assessing the relationships between the two. For depression, the BDI is certainly one of the most widely used self-report measures. It is composed of the dimensions somatic-performance, cognitive-affective and selfblame, which assess cognitive and somatic symptoms. ${ }^{13}$ Specifically, several of the somatic topics could be more related to excess weight than to the depression itself, leading to false-positive results. ${ }^{27}$ The Center for Epidemiologic Studies Depression Scale, which also evaluates somatic symptoms, is another example of a recognized resource for the identification of depressive symptoms. ${ }^{28}$ The main instruments for the evaluation of anxiety include the Hamilton, Zung and Beck scales. These three scales have similar constructs, with an emphasis on the somatic aspects of anxiety. ${ }^{29}$ It is also of note that body weight can interfere with the application of various diagnostic instruments used in clinical practice and research, particularly those that evaluate somatic symptoms.

Our study has some limitations. First, the SCL-90 is an instrument designed to evaluate a broad range of psychological problems and psychopathological symptoms. ${ }^{15,28}$ However, some studies suggest that this test is inappropriate, mainly in the evaluation of the anxiety and obsessive-compulsive subscales. With the purpose of correcting these potential flaws, the original scales were revised, resulting in the revised SCL-90 and the Brief Symptom Inventory. ${ }^{30}$ Second, our analysis included only obese individuals. We cannot ascertain whether the same results would be obtained if normal-weight and overweight individuals were included. Third, the lack of a specific psychiatric evaluation might have hampered the interpretation of the reported symptoms. It is well known that patients reports related to their symptoms or to objective subjects, such as observable behaviors, might not correlate with the data provided by other observers and might not correspond to the impressions given in the clinical interview. However, it is well established that these screening scales constitute a reasonable method for the evaluation of psychopathology, especially when psychiatric evaluation is unavailable. Therefore, the severity of the disease can be predicted. In addition, the empirical results obtained through the application of these scales in the general population consistently show that the extracted factorial structures are similar to those that of the psychiatric nosology. ${ }^{31}$

In conclusion, our results suggest that the degree of obesity is not associated with a complex psychopathological profile. These results stand in contrast to most of the findings published to date. Two main hypotheses might explain these contradictory findings: first, there are other features in obese patients that correlate with a worse psychopathological profile; and second, most instruments used in order to evaluate psychiatric symptoms assess somatic symptoms. These instruments might not be reliable for the evaluation of obese patients, since obesity, per se, correlates directly with somatic symptoms. Studies involving the use of specific instruments are necessary in order to determine whether excess weight is associated with specific psychiatric symptoms, or whether the instruments currently used are only indirectly measuring symptoms primarily attributable to obesity itself.

\section{Disclosures}

\begin{tabular}{|c|c|c|c|c|c|c|c|}
\hline $\begin{array}{l}\text { Writting group } \\
\text { member }\end{array}$ & Employment & $\begin{array}{l}\text { Research } \\
\text { grant }^{1}\end{array}$ & $\begin{array}{l}\text { Other research grant } \\
\text { or medical continuous } \\
\text { education }\end{array}$ & $\begin{array}{l}\text { Speaker's } \\
\text { honoraria }\end{array}$ & $\begin{array}{c}\text { Ownership } \\
\text { interest }\end{array}$ & $\begin{array}{l}\text { Consultant/ } \\
\text { Advisory } \\
\text { board }\end{array}$ & Other ${ }^{3}$ \\
\hline Marcelo Papelbaum & UFRJ & - & - & - & - & - & - \\
\hline Carolina Preissler & - & - & - & - & - & - & - \\
\hline $\begin{array}{l}\text { Walmir Ferreira } \\
\text { Coutinho }\end{array}$ & $\begin{array}{c}\text { IEDE } \\
\text { PUC-RJ }\end{array}$ & - & - & - & - & - & - \\
\hline $\begin{array}{l}\text { * Modest } \\
\text { * Significant } \\
{ }^{* *} \text { Significant. Amoun } \\
\text { Note: UFRJ = Univers } \\
\text { Diabetes e Endocrinol }\end{array}$ & $\begin{array}{l}\text { en to the author's } \\
\text { Federal do Rio d }\end{array}$ & aneiro; PUC & $\begin{array}{l}\text { olleague for research in } \\
J=\text { Pontifícia Universida }\end{array}$ & $\begin{array}{l}\text { ich the auth } \\
\text { Católica do }\end{array}$ & $\begin{array}{l}\text { has particip } \\
\text { o de Janeir }\end{array}$ & $\begin{array}{l}\text { not directly } \\
D E=\text { Institu }\end{array}$ & $\begin{array}{l}\text { the au } \\
\text { stadu }\end{array}$ \\
\hline
\end{tabular}

References

1. Instituto Brasileiro de Geografia e Estatística - IBGE. Estudo Nacional da Despesa Familiar (ENDEF): dados preliminares, consumo alimentar - antropométrica. Rio de Janeiro, 1977. In: Pesquisa de Orçamentos Familiares (POF) 2002 - 2003. Análise da disponibilidade domiciliar de alimentos e estado nutricional no Brasil. Rio de Janeiro: IBGE; 2005. 80p.
2. Moller DE, Kaufman KD. Metabolic syndrome: a clinical and molecular perspective. Annu Rev Med. 2005;56:45-62.

3. Garber AJ. The metabolic syndrome. Med Clin North Am. 2004;88(4):837-46. 4. Bouchard C. Genetics of obesity: overview and research direction. In: Bouchard C, editors. The genetics of obesity. Florida: Boca Raton; 1994. p.223-33.

5. Price R. Genetics and common obesities: background, current status, strategies, end future prospects. In: Wadden T, Stunkard AJ, editors. Handbook for obesity treatment. New York: Guilford; 2002. p.73-94. 
6. Friedman M, Brownell KD. Psychological consequences of obesity. In: Fairbum CG, editors. Eating disorders and obesity. 2nd ed. New York: Greford Press; 2002. p.393-8.

7. Freitas CS, Lopes CS, Apollinário JC, Coutinho W. The assessment of binge eating disorder in obese women: a comparison of the binge eating scale with the structured clinical interview for the DSM- IV. Eat Behav. 2006;7(3):282-9.

8. Teng CT, Humes EC, Demetrio FN. Depressão e comorbidades clínicas. Rev Psiquiatr Clin. 2005;32(3):149-59.

9. Dobrow IJ, Kamenetz C, Devlin MJ. Aspectos psiquiátricos da obesidade. Rev Bras Psiquiatr. 2002;24(3):63-7.

10. Gorestein C, Andrade LHSG, Zuardi AW. Escalas de avaliação clínica em psiquiatria e psicofarmacologia. Rev Psiquiatr Clin. 1998;26(1):65-9.

11. Derogatis LR, Cleary PA. Confirmation of the dimensional structure of the SCL-90: a study in construct validation. J Clin Psychol. 1977;33:981-9.

12. Laloni DT. Escala de avaliação de sintomas SCL-90-R: adaptação, precisão e validade [dissertation]. Campinas: Pontifícia Universidade Católica de Campinas; 2007.

13. Gorenstein C, Andrade L, Vieira Filho AH, Tung TC, Artes R. Psychometric properties of the Portuguese version of the beck depression inventory on Brazilian college students. J Clin Psychol. 1996;55(5):553-62.

14. Hach I, Ruhl UE, Klose M, Klotsche J, Kirsh W, Jacob F. Obesity and the risk for mental disorders in a representative german adult sample. Eur J Public Health. 2007;17(3):297-305.

15. Petroni ML, Villanova N, Avagnina S, Fusco MA, Fatati G, Compare A, Marchesini G. Psychological distress in morbid obesity in relation to weight history. Obes Surg. 2007;17(3):391-9.

16. Rosik $\mathrm{CH}$. Psychiatric symptoms among prospective bariatric surgery patients: Rates of prevalence and their relation to social desirability, pursuit of surgery, and follow-up attendance. Obes Surg. 2005;15(5):677-83.

17. Guisado, JA, Vas FJ, Alarcón J, Casado M. Psicopatologia em pacientes com obesidad mórbida poscirurgia gástrica. Rev Cubana Endocrinol. 2002;13(1):19-34.

18. Lipowski ZJ. Somatization: the concept and its clinical application. Am J Psychiatry. 1988;145(11):358-68.

19. Fellipe FML, Friedman R, Alves BS, Cibeira GH. Obesidade e mídia: o lado sutil da informação. Rev Acad Grupo Comunicacional de São Bernardo. 2004; $2: 1-5$.

20. Sullivan S, Cloninger CR, Prgbeck TR, Klein S. Personality characteristics in obesity and relationship with successful weight loss. Int J Obes. 2007;31(4):669-74.

21. Istvan J, Zavela K, Weidner G. Body weight and psychological distress in NHANES I. Int J Obes. 2002;16(12):999-1003.

22. Stunkard AJ, Faith MS, Allison KC. Depression and obesity. Biol Psychiatry. 2003;54(3):330-7.

23. Sanches- Roman S, Lopes-Alvarenga JC, Vargas-Matines A, Telles-Zenteno JF. Prevalence of Psychiatric disorders in patients with severe obesity waiting for bariatric surgery. Rev Invest Clin. 2003;55(4):400-6.

24. Simon GE, Korff MV, Saunders K, Miglioretti DL, Crane PK, van Belle G, Kessler RC. Association between obesity and psychiatric disorders in the US adult population. Arch Gen Psychiatry. 2006;63(7):824-30.

25. Moreira RO, Marca KF, Appolinario JC, Coutinho WC. Increased waist circumference is associated with an increased prevalence of mood disorders and depressive symptoms in obese women. Eating Weight Disord. 2007;12(1):35-44.

26. Fabricatore AN, Wadden TA. Psychological aspects of obesity. Clin Dermatol. 2004;22(4):332-7.

27. Moreira RO, Zen MS. Anthropometric indicators of overweight and the Beck Depression Inventory: an association to be considered. Rev Bras Psiquiatr. 2007:29(2):188-9.

28. Silveira DX, Jorge MR. Propriedades psicométricas da escala de rastreamento populacional para depressão CES-D em populações clínicas e não-clínicas de adolescentes e adultos jovens. Rev Psiq Clin. 1988;25(5):251-61.

29. Andreoli SB, Blay SL, Mari JJ. Escalas de rastreamento de psicopatologia. Rev Psiq Clin. 1999;25(5):229-32.

30. Derogatis LR, Lazaros L. SCL-90-R, brief symptom inventory, and matching clinical rating scales. In: Maruish M, editors. The use of psychological testing for treatment planning and outcome assessment. Hillsdale, NJ: Lawrence Erlbaum; 1994. p.217-48.

31. Leombruni P, Piero A, Dosio D, Novelli A, Abbate-Daga G, Morino M, Toppino M, Fassino S. Psychological Predictors of Outcome in Vertical Banded Gastroplasty: a 6 Months Prospective Pilot Study. Obes Surg. 2007;25(5):229-32. 